\title{
Cytoenzymatical differentiation of normal and neoplastic plasma cells
}

\author{
STANISLAW SZMIGIELSKI, JOANNA LITWIN, AND BARBARA ZUPANSKA \\ From the Department of Clinical Haematology, \\ State Institute of Haematology, Warsaw, Poland
}

SYNOPSIS A histochemical method is described of differentiating between normal and neoplastic cells in plasma using the activity of various enzymes characteristic of plasma cells. It was found that in both types of cell increased or diminished activity of cytoenzymes is a useful means of distinguishing between normal and abnormal cells.

The active protein metabolism and activity of various enzymes are the characteristic features of plasma cells (Lajtha, 1957). In normal plasma cells non-specific acid phosphatase esterase (Löffler and Schubert, 1963) and arylsulphatase (Austin and Bischel, 1961) were demonstrated. The histochemical differentiation by phosphatases and esterase in normal and neoplastic plasma cells has been established (Löffler and Schubert, 1963; Schubert and Rinneberg, 1962), and decreased activity of adenosine-triphosphatase (A.T.P.-ase) and increased activity of non-specific acid phosphatase and esterase were observed in neoplastic plasma cells (Löffler and Schubert, 1963). The purpose of this paper is to investigate the activity of some specific phosphatases, namely, A.T.P.-ase, thiamine-pyro-phosphatase (T.P.P.-ase), glucose-6phosphatase (G-6-P-ase), non-specific esterases, and gamma-glutamyl transpeptidase (G.G.T.P.) in normal and neoplastic plasma cells using histochemical techniques.

\section{MATERIAL AND METHODS}

Bone marrow smears of 15 healthy adults, three subjects with plasma-cell reaction (two of them suffering from hepatic cirrhosis and one from lupus erythematosus), and eight patients with multiple myeloma were investigated.

In all smears A.T.P.-ase activity was demonstrated using Wachstein's procedure modified by Schubert and Rinneberg (1962); T.P.P.-ase activity by the method of Novikoff and Goldfischer (1961); G-6-P-ase activity by the method of Allen (1961); non-specific esterase using $\beta$-naphthyl acetate and 5-bromine-indoxyl acetate as the substrates, according to the methods described by Pearson and Defendi (1957); G.G.T.P. activity with $\mathrm{L}$-( $\gamma$-glutamyl)- $\alpha$-naphthylamide as substrate, according to the procedure described by Albert, Orlowski, and

Received for publication 25 September 1964.
Szewczuk (1961) and Glenner, Folk, and McMillan (1962).

All slides for enzyme demonstration, except those for G-6-P-ase, were fixed for four minutes in cold $\left(4^{\circ} \mathrm{C}\right.$.) formalin vapour and carefully rinsed in distilled water. Slides for the demonstration of G-6-P-ase activity were fixed for 10 seconds in cold $\left(4^{\circ} \mathrm{C}\right.$.) $96 \%$ ethyl alcohol and carefully rinsed in distilled water. Incubation solutions and the time of incubation were those described in the methods quoted. Enzyme activity in plasma cells was defined as the percentage of active cells.

\section{RESULTS}

ADENOSINE-TRIPHOSPHATASES About $60 \%$ of plasma cells from normal bone marrow showed marked $(++)$ activity (Fig. 1) and the remaining $40 \%$ weaker $(+)$ activity. The enzyme was localized in the cytoplasm and in some cells near the nucleus. No A.T.P.-ase activity was observed in the nucleus. Reactive plasma cells showed similar A.T.P.-ase activity to that observed in normal bone marrow. In neoplastic plasma cells a marked decrease in A.T.P.-ase activity was visible (Fig. 3). Few granulations appeared in 5 to $15 \%$ of these cells.

THIAMINE-PYRO-PHOSPHATASE Strong activity was observed in $38 \%$ of normal and reactive plasma cells (Fig. 2) but none was visible in neoplastic plasma cells (Fig. 4).

GLUCOSE-6-PHOSPHATASE In $50 \%$ of normal and reactive plasma cells slight activity was visible, but none of the neoplastic plasma cells was active.

NON-SPECIFIC ESTERASE Activity was investigated with the use of $\beta$-naphthyl acetate and 5-bromineindoxyl acetate as the substrates. Both techniques 


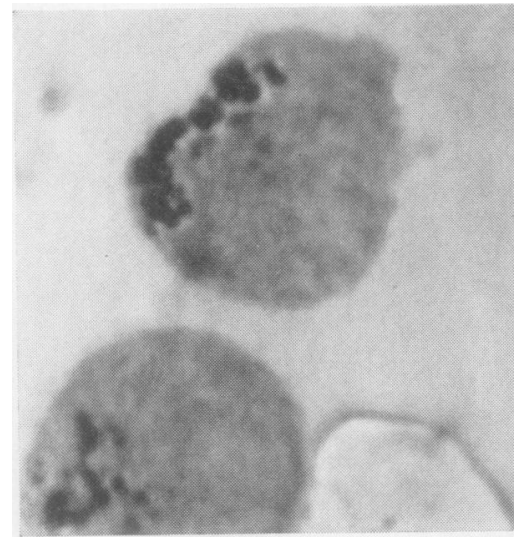

FIG. 1.

FIG. 2.

FIG. 1. Marked $(++)$ A.T.P.-ase activity in normal plasma cells.

FIG. 2. Glucose-6-phosphatase activity in normal plasma cell.

FIG. 3. Lack of A.T.P.-ase activity in neoplastic plasma cell.

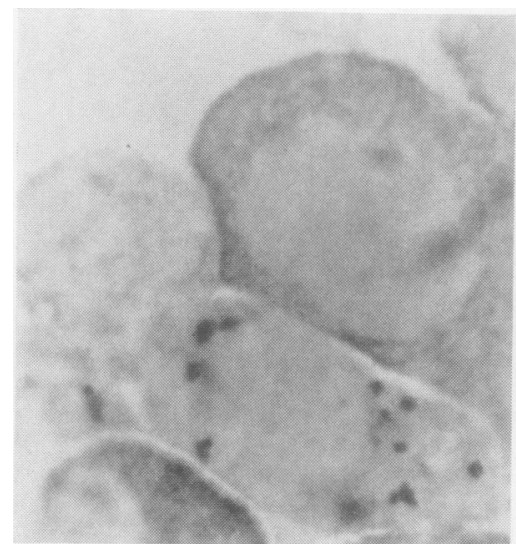

FIG. 4.

\section{FIG. 5.}

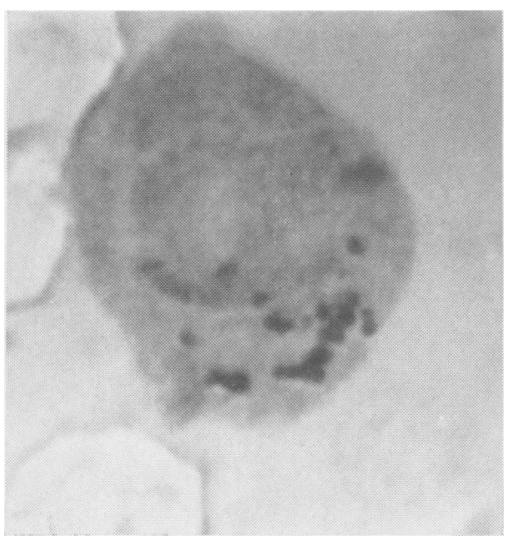

FIG. 4. Lack of G-6-P-ase activity in neoplastic plasma cell.

FIG. 5. Non-specific esterase activity in normal plasma cell (indoxyl method).

FIG. 6. Gamma glutamyl transpeptidase activity in reactive plasma cells.



FIG. 7.



FIG. 8 .

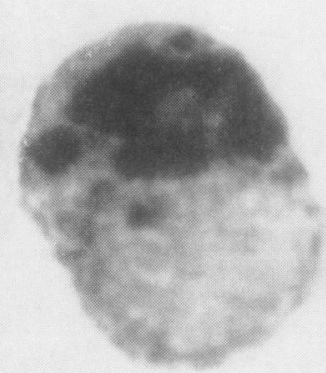

FIG. 6 .

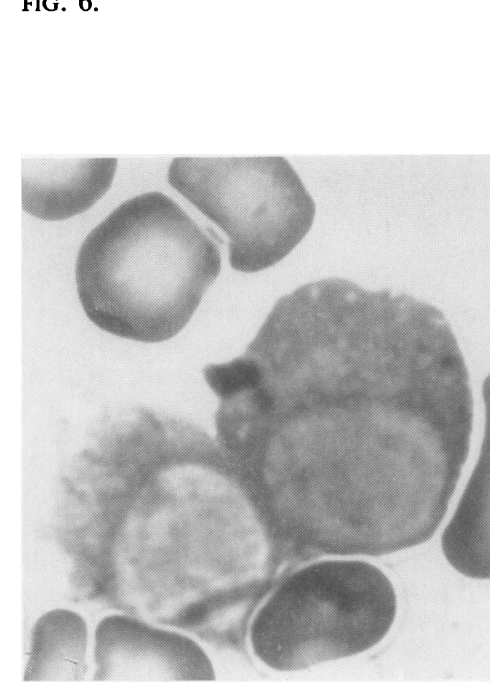

FIG. 9.
FIG. 3.

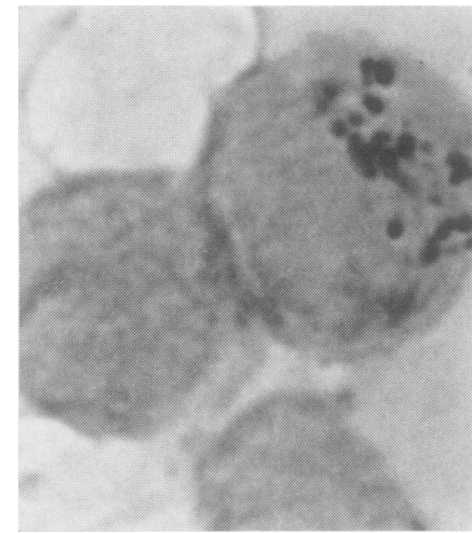

FIG. 7. Increased activity of non-specific esterase in neoplastic plasma cell (indoxyl method).

FIG. 8. Increased activity of non-specific esterase in neoplastic plasma cell (naphthyl-acetate method).

FIG. 9. Lack of G.G.T.P. activity in neoplastic plasma cells. 
TABLE I

DIFFERENTIATION OF NORMAL AND NEOPLASTIC PLASMA CELLS BY CYTOENZYMES

\begin{tabular}{|c|c|c|c|c|}
\hline \multirow{2}{*}{$\begin{array}{l}\text { Adenosine } \\
\text { Triphosphatase }\end{array}$} & \multirow{2}{*}{$\begin{array}{l}\text { Thiamine-pyro- } \\
\text { phosphatase }\end{array}$} & \multirow{2}{*}{$\begin{array}{l}\text { Glucose-6- } \\
\text { phosphatase }\end{array}$} & Esterase & \multirow{2}{*}{$\begin{array}{l}\text { Gamma Glutamyl } \\
\text { Transpeptidase }\end{array}$} \\
\hline & & & Non-specific ${ }^{1}$ & \\
\hline
\end{tabular}

\begin{tabular}{|c|c|c|c|c|c|c|}
\hline Normal plasma cell & $\begin{array}{r}++(60 \%) \\
+(40 \%)\end{array}$ & $++(38 \%)$ & $+(50 \%)$ & + & + & $++(60 \%)$ \\
\hline Reactive plasma cell & $\begin{array}{r}+ \\
++\end{array}$ & $+t$ & + & + & + & $+t$ \\
\hline Neoplastic plasma cell & $+(5-15 \%)$ & - & - & $++t$ & $+t+$ & - \\
\hline
\end{tabular}

gave the same results. Fifty per cent of normal and reactive plasma cells showed activity after being treated with $\beta$-naphthyl acetate and $45-55 \%$ were active when incubated with 5-bromine-indoxyl acetate. By both techniques activity of these cells was defined as slight to moderate $(+$ and ++$)$ (Fig. 5). Neoplastic plasma cells (Figs. 7 and 8) showed a marked increase in esterase activity $(+++$ and ++++ ). In some of these cells big aggregates of dye were found (Fig. 8). Eighty to ninety per cent of neoplastic plasma cells were active after treating with $\beta$-naphthyl acetate and 70 to $86 \%$ after incubation with 5-bromine-indoxyl acetate.

GAMMA-GLUTAMYL TRANSPEPTIDASE About $60 \%$ of normal and reactive plasma cells showed moderate $(++)$ or strong $(+++)$ activity (Fig. 6). In neoplastic plasma cells a marked decrease in activity was observed (Fig. 9). Only 14 to $30 \%$ of these cells showed slight activity. Other neoplastic plasma cells were negative.

The results are summarized in Table I.

\section{DISCUSSION}

The investigation of normal and neoplastic plasma cell metabolism was carried out to try and explain the disturbances in protein and antibody synthesis in multiple myeloma (McMillan and Engelbert, 1963; Müller, 1963; Sundberg, 1955). In normal plasma cells the active protein synthesis was established but synthesis of nucleic acids was only slight (Lajtha, 1957). Increased D.N.A. synthesis in neoplastic plasma cells (Müller, 1963) was until recently the only demonstrated biochemical disorder differentiating multiple myeloma cells from normal plasma cells. But Löffler and Schubert (1963) and Schubert and Rinneberg (1962) have demonstrated the dedecreased activity of A.T.P.-ase and increased activity of non-specific acid phosphatase and esterase. Decreased A.T.P.-ase activity is probably due to failure in organic and glycolytic metabolism of neoplastic cells (Aisenberg, 1961). The hydrogen ion concentration $p \mathrm{H} \mathrm{7.2} \mathrm{(Schubert} \mathrm{and} \mathrm{Rinneberg,}$ 1962) makes possible the simultaneous demonstration of two species of A.T.P.-ase, nuclear and cytoplasmic (Bankowski, 1963). Both these enzymes were demonstrated in normal hepatic cells (Bankowski, 1963). For an explanation of disorders in A.T.P.-ase in neoplastic plasma cells it would be of interest to demonstrate nuclear and cytoplasmic A.T.P.-ase separately (incubating at $p \mathrm{H} 5.9$ and 8.4) and to compare the results.

Decreased G-6-P-ase activity in neoplastic plasma cells is similar to the behaviour of this enzyme in leukaemic myeloblasts (Valentine, 1960; Weber and Cantero, 1955) and in cells from experimental neoplasms (Van Potter, 1963).

The meaning of diminished T.P.P.-ase activity in neoplastic plasma cells is difficult to explain, since the role of cocarboxylase and thiamine in cell metabolism and physiology is still insufficiently known.

The increased esterase activity in neoplastic plasma cells was established with the use of both $\beta$-naphthyl acetate and 5-bromine-indoxyl acetate as substrates. Investigations performed with naphtholAS-acetate and naphthol-AS-D-chloroacetate (Löffler and Schubert, 1963) have shown no differences in esterase activity in normal and neoplastic plasma cells, the results indicating an increased activity of some groups of esterases only, but these enzymes cannot be fully defined, since histochemical methods for esterase activity have no specificity (Ackerman, 1960). Investigations of G.G.T.P. activity in plasma cells have not previously been performed. Gamma-glutamyl transpeptidase is an enzyme catalysing the transformation of $\gamma$-glutamyl molecules from one peptide to another (Orlowski, 1963), and changes in its activity are probably related to disorders in glutathion metabolism (Albert et al., 1961; Glenner et al., 1962). Decreased activity in neoplastic plasma cells seems to be connected with damaged protein synthesis in these cells. It would be of interest to investigate histochemically the activity of other peptidases in plasma cells.

Till now only leucine-amine-peptidase activity has 
been investigated (Löffler and Schubert, 1963), and both normal and neoplastic cells have shown no activity.

\section{REFERENCES}

Ackerman, G. A. (1960). Lab. Invest., 9, 298.

Aisenberg, A. C. (1961). The Glycolysis and Respiration of Tumors, Academic Press, New York and London.

Albert, Z., Orlowski, M., and Szewczuk, A. (1961). Nature (Lond.), $191,767$.

Allen, J. M. (1961). J. Histochem. Cytochem., 9, 681.

Austin, J. H., and Bischel, M. (1961). Blood, 17, 216.
Bankowski, Z. (1963). Folia histochem. cytochem., 1, 17. Glenner, G. G., Folk, J. E., and McMillan, P. J. (1962). J. Histochem Cytochem., 10, 481

Lajtha, L. G. (1957). Physiol. Rev., 37, 50.

Löffier, H., and Schubert, J. C. F. (1963). Klin. Wschr., 41, 484.

McMillan, D. B., and Engelbert, V. E. (1963). Amer. J. Path., 42, 31

Müller, D. (1963). Med. Welt (Stuttg.), 32, 1794.

Novikoff, A. B., and Goldfischer, S. (1961). Proc. nat. Acad. Scte (Wash.) 47, 802 .

Orlowski, M. (1963). Arch. Immunol. Ther. Exp., 11, 1.

Pearson, B., and Defendi, V. (1957). J. Histochem. Cytochem., 5, 72 की
Schubert, J. C. F., and Rinneberg, H. (1962). Blut, 8, 282.

Sundberg, D. R. (1955). Ann. N.Y. Acad. Sci., 59, 671.

Valentine, W. N. (1960). Amer. J. Med., 28, 699.

Van Potter, R. (1963). Advanc. Enzyme Regul., 1, 279.

Weber, G., and Cantero, A. (1955). Cancer Res., 15, 105. 